\title{
Evaluation of Treatment Results with Direct Acting Antiviral Drugs of Cirrhotic/Non-cirrhotic Chronic Liver Disease Caused by Hepatitis C Virus Genotype 1 b Infection
}

\section{Hepatit C Virüs Genotip 1b Kaynakıı Sirotik/Sirotik Olmayan Kronik Karaciğer Hastalığı Olgularında Doğrudan Etkili Antiviral Ilaç Tedavisi Sonuçlarının Değerlendirilmesi}

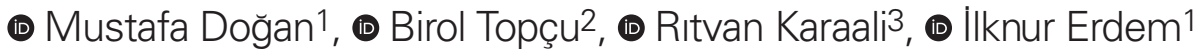 \\ ${ }^{1}$ Namık Kemal University Faculty of Medicine, Department of Infectious Diseases, Tekirdağ, Turkey \\ 2 Namık Kemal University Faculty of Medicine, Department of Biostatistics, Tekirdağ, Turkey \\ 3/stanbul University-Cerrahpaşa, Cerrahpaşa Faculty of Medicine, Department of Infectious Diseases, Istanbul, Turkey
}

\begin{abstract}
Objectives: This study aimed to investigate the effect of treatment with direct-acting antivirals (DAAs) on the virological response and on the some parameters used to evaluate liver function in cases with chronic liver disease due to hepatitis $\mathrm{C}$ virus (HCV) genotype $1 \mathrm{~b}$.

Materials and Methods: This study included cases who were treated with DAAs after HCV genotype $1 \mathrm{~b}$ infection. HCV-RNA levels and biochemical and hematological parameters measured at the beginning of treatment, $12^{\text {th }}$ week and $52^{\text {th }}$ week after the treatment were transferred to the SPSS statistics software. model for end-stage liver disease (MELD) and Child-Pugh scores were also calculated and added to these data.

Results: The study group consisted of a total of 102 patients, including $33(32 \%)$ males and $69(68 \%)$ females. Compensated cirrhosis was detected in $26.5 \%$ of the patients $(n=27)$. There was a significant change in serum albumin, alanine aminotransferase (ALT), aspartate aminotransferase (AST), gamma-glutamyl transferase (GGT) and alphafetoprotein (AFP) parameters in patients with compensated cirrhosis after treatment, and total bilirubin, hemoglobin, ALT, AST, GGT, ALP and AFP parameters in the group without cirrhosis $(p<0.05)$. Only a significant decrease was observed in the MELD score of the patients with compensated cirrhosis ( $p=0.007$ ).

Conclusion: The ombitasvir/paritaprevir/ritonavir+dasabuvir and ledipasvir/sofosbuvir regimens are very effective and safe in the treatment of patients who develop chronic liver disease and compensated liver cirrhosis after HCV genotype $1 \mathrm{~b}$ infection.
\end{abstract}

Keywords: HCV, PrOD, MELD, Child-Pugh, compansated cirrhosis

\section{$0 ̈ z$}

Amaç: Bu çalışmanın amacı, hepatit C virüs (HCV) genotip 1b'ye bağlı kronik karaciğer hastalığı gelişen olgularda, doğrudan etkili antiviral (DEA) ilaçlar ile yapılan tedavinin virolojik yanıt ve karaciğer fonksiyonlarını değerlendirmek için kullanılan bazı parametreler üzerine etkisinin irdelenmesidir.

Gereç ve Yöntemler: Retrospektif bir çalışmadır. Bu çalışmaya HCV genotip $1 \mathrm{~b}$ enfeksiyonu sonrası DEA ilaçlar ile tedavi edilen 18 yaşından büyük olgular dahil edildi. Tedavi başlangıcı, 12. ve 52. haftalara ait HCVRNA düzeyi, biyokimyasal ve hematolojik parametreler SPSS istatistik programına aktarıldı. Bu verilere, son dönem karaciğer hastalığı için model (MELD) ve Child-Pugh skorları da hesaplanarak eklendi.

Bulgular: Çalışma grubu 33'ü (\%32) erkek, 69'u (\%68) kadın 102 hastadan oluşmaktadır. Hastaların \%19'unda $(n=20)$ kompanse siroz saptandı. Tedavi sonrası kompanse sirozu olan hastalarda serum albümin, alanin aminotransferaz (ALT), aspartate aminotransferas (AST), gama glutamil transferaz (GGT) ve alfa Fetoprotein (AFP) parametrelerinde, sirotik olmayan grupta ise total biluribin, hemoglobin, ALT, AST, GGT, ALP ve AFP parametrelerinde anlamlı değişiklik saptandı $(p<0,05)$. Siroz olmayan hastaların MELD ve Child skorlarının puan değeri tedavi sonrası azalmakla birlikte anlamlı değişiklik olmadı. Kompanse sirozu olan hastaların ise yalnız MELD skorunda anlamlı bir azalma $(p=0.007)$ saptandı.

Sonuç: Ombitasvir/paritaprevir/ritonavir+dasabuvir ve sofosbuvir/ ledipaspir rejimleri, HCV genotip 1b enfeksiyonundan sonra kronik karaciğer hastalığı ve kompanse karaciğer sirozu gelişen hastaların tedavisinde çok etkili ve güvenlidir.

Anahtar Kelimeler: HCV, PrOD, MELD, Child-Pugh, kompanse siroz

Doğan M, Topçu B, Karaali R, Erdem İ. Evaluation of Treatment Results with Direct Acting Antiviral Drugs of Cirrhotic/Non-cirrhotic Chronic Liver Disease Caused by Hepatitis C Virus Genotype 1b Infection. Viral Hepat J. 2020;26:43-48. 


\section{Introduction}

Hepatitis C virus (HCV) is known as the single-stranded, enveloped, smallest RNA virus of the Flaviviridae family. It is divided into at least six groups and many subtypes according to its genotype. Although different rates are reported regionally in different studies reported from Turkey, the most frequently seen genotype is $1 \mathrm{~b}$ (1). Chronic HCV infection is one of the most important causes of chronic liver disease, hepatocellular carcinoma, and cirrhosis. More than 185 million people worldwide are thought to be infected with $\mathrm{HCV}$ and more than 85.000 people in Turkey (1). About $60-85 \%$ of these cases become chronic (2). An effective treatment is of great importance in terms of breaking the infection chain, preventing the spread and reducing the morbidity and mortality caused by the virus. With the introduction of direct-acting antivirals (DAAs), a sustained virologic response (SVR) of up to $99 \%$ has been achieved in the treatment of these patients, leading to the beginning of a new period (3). A limited number of cases have been reported to discontinue treatment due to side effects and unforeseen causes during the treatment. However, these drugs provided satisfactory results in the follow-up of the disease with their ease of use, easy tolerance and low side effect profiles (4). This study aimed to investigate the treatment results obtained with DAAs in patients with HCV genotype $1 \mathrm{~b}$ and the effect of this treatment on some laboratory parameters evaluating liver damage and on the score values obtained from the scoring methods.

\section{Materials and Methods}

This is an observational study aimed at collecting retrospective data. This study was carried out with the approval of Ethical Committee of Namık Kemal University Faculty of Medicine (approval number 2020.86.04.10). The procedures were performed in accordance with the Declaration of Helsinki. Since our study was retrospective, informed consent was not used. This study covered the date range of 01.01.2016-31.12.2019. Patients older than 18 years of age, who were evaluated in our outpatient clinic within the specified date range, had anti-HCV positivity and received DAA medication, were included. The study group consisted of 102 cases. Demographic data, serological data, sustainable virological response, treatment regimen and side effects were transferred to the study form. The HCV-RNA values measured before the treatment, end of the treatment and $52^{\text {th }}$ week, as well as biochemical and hematological analysis results, were also recorded in the study form. The model for end-stage liver disease (MELD) and Child-pugh scores of these patients were also calculated and transferred to the form.

\section{Statistical Analysis}

Data were transferred to the study form and analyzed using SPSS statistical software. Variables were expressed in frequency, percentage, mean, standard deviation, table, and graph. The normality test was performed and all variables were seen to follow a normal distribution. Paired Samples test was used to compare the pre- and post-treatment values of the continuous variables. A p-value of $<0.05$ was considered statistically significant.

\section{Results}

Of the 153 patients, $15 \%(n=23)$ were seen not to come to regular polyclinic controls and $18 \%(n=28)$ were other genotypes.
The study group consisted of 102 patients with genotype $1 \mathrm{~b}$. The mean age of these patients was $59.43 \pm 14$ years (minimum: 21, maximum: 83). Of the cases, $32 \%(n=33)$ were male and $68 \%$ $(n=69)$ were female. Of the patients, $82 \%(n=84)$ were naive and $17 \%(n=17)$ previously received pegylated interferon plus ribavirin treatment and one case received boceprevir with peginterferon alfa-2a-ribavirin treatment. Compensated cirrhosis diagnosis was observed in $26.5 \%$ of the patients $(n=27)$. In the treatment of $82 \%$ of patients, the ombitasvir/paritaprevir/ritonavir tablet 12.5/75/50 mg once a day two tablets at the same time and dasabuvir (PrOD) tablet $250 \mathrm{mg}$ twice daily regimen was seen to be used whereas Sofosbuvir/ledipasvir 400/90 mg once a day regimen was used in the treatment of $18 \%$. Demographic characteristics and clinic parameters of patients before treatment are shown in Table 1.

Table 1. Demographic characteristics and clinic parameters of patients

\begin{tabular}{|c|c|}
\hline Characteristic & $\mathrm{n}(\%)$ \\
\hline Age & $59.43 \pm 14$ \\
\hline \multicolumn{2}{|l|}{ Sex } \\
\hline Female & $69(68)$ \\
\hline Male & $33(32)$ \\
\hline \multicolumn{2}{|l|}{ Genotype } \\
\hline Genotype 1b & $102(100)$ \\
\hline \multicolumn{2}{|l|}{ Treatment history } \\
\hline Naiv & $84(82.4)$ \\
\hline Pegylated interferon/ ribavirin & $17(16.7)$ \\
\hline $\begin{array}{l}\text { Bocepravir + pegylated interferon } \\
\text { alfa } 2 \text { A/ribavirin }\end{array}$ & $1(0.09)$ \\
\hline \multicolumn{2}{|l|}{ Liver disease } \\
\hline No cirrhosis & $75(73.5)$ \\
\hline Compensated cirrhosis & $27(26.5)$ \\
\hline \multicolumn{2}{|c|}{ Antiviral treatment in patients without cirrhosis } \\
\hline $\begin{array}{l}\text { Ombitasvir/paritaprevir/ritonavir + } \\
\text { dasabuvir }\end{array}$ & $57(76)$ \\
\hline Sofosbuvir/ledipasvir & $18(24)$ \\
\hline \multicolumn{2}{|c|}{ Antiviral therapy in patients with compensated cirrhosis } \\
\hline $\begin{array}{l}\text { Ombitasvir/paritaprevir/ritonavir+ } \\
\text { dasabuvir }\end{array}$ & $26(96)$ \\
\hline Sofosbuvir/ledipasvir & $1(4)$ \\
\hline \multicolumn{2}{|l|}{ HAI } \\
\hline No cirrhosis & $7.2 \pm 2.1$ \\
\hline Compensated cirrhosis & $10.1 \pm 1.8$ \\
\hline \multicolumn{2}{|l|}{ HCV-RNA level } \\
\hline No cirrhosis & $\begin{array}{l}2235654,094 \pm 4707658,56 \\
\mathrm{IU} / \mathrm{mL} \\
\text { (minimum: } 675, \\
\text { maximum: } 31437735 \text { ) }\end{array}$ \\
\hline Compensated cirrhosis & $\begin{array}{l}\text { 737205,53 } 388069,64 \\
\mathrm{IU} / \mathrm{mL} \\
\text { (minimum: } 79127, \\
\text { maximum: } 5177768 \text { ) }\end{array}$ \\
\hline
\end{tabular}


There was no statistically significant difference in terms of treatment success in both groups ( $p>0.05$ ). In $99 \%$ of the patients ( $n=101), H C V-R N A$ levels were found below the determinable level in the fourth week of treatment. The SVR was found to be $99 \%$ at 12 weeks after treatment. In the evaluation of a case where no virological response was seen, it was learned that the patient was anti-human immunodeficiency virus (HIV) positive, received antiretroviral therapy (elvitegravir/cobicistat/emtricitabine/tenofovir disoproxil), and was using an intravenous agent. In the evaluation made at the $52^{\text {th }}$ week after treatment, recurrence (HCV-RNA: 4277 $\mathrm{IU} / \mathrm{mL}$ ) was detected in one case, while SVR maintained in other cases. No detectable risk factor was found in the recurrent case. No patient discontinued the treatment due to adverse effects. There was no relationship between advanced age [ $\geq 65$ years $(n=47),<65$ years $(n=55)$ ] and treatment success among the cases.

Considering the pre- and post-treatment laboratory parameters, there was a significant change in serum albumin, alanine aminotransferase (ALT), aspartate aminotransferase (AST), gammaglutamyl transferase (GGT) and alpha-fetoprotein (AFP) parameters in patients with compensated cirrhosis after treatment, and total bilirubin, hemoglobin, ALT, AST, GGT, ALP and AFP parameters in the group without cirrhosis $(p<0.05)$. The MELD and CHILD scores of patients without cirrhosis were seen to decrease after treatment, but this decrease was not significant. However, there was a significant decrease in the MELD score of patients with compensated liver cirrhosis $(p=0.007)$. Descriptive statistics of surveyed variables among patient are shown in Table 2.

\section{Discussion}

This retrospective single-center study consists of real-life data obtained between 2016-2019. Chronic HCV infection is one of the most important causes of cirrhosis and related liver diseases. The
SVR achieved following an effective treatment significantly reduces morbidity and mortality even in advanced fibrosis (5). High levels of success have been achieved via both PrOD-based and sofosbuvirbased treatment regimens in the treatment of cases with $\mathrm{HCV}$ genotype $1 \mathrm{~b}$ (6). The SVR rate has been reported to vary between $84 \%$ and $100 \%$ depending on patient groups and risk factors $(7,8)$. The presence of liver cirrhosis stands out as an independent risk factor affecting SVR-12 (6). However, high SVR-12 can be achieved regardless of the liver cirrhosis stage (9). Treatment success (SVR12) has been found to be higher in patients with albumin $>3.5 \mathrm{~g} / \mathrm{dL}$, bilirubin $<2 \mathrm{mg} / \mathrm{dL}$ and Child-pugh scores score 5-6 in the presence of liver cirrhosis (10). Furthermore, in a different evaluation, 100\% SVR-12 was obtained with the PrOD regimen in the group, where $98.4 \%$ of patients had a Child-pugh score of 5 points, and no side effects that could lead to the discontinuation of treatment were observed (11).

Progression to decompensation can be seen in patients with compensated cirrhosis during the PrOD-based treatment regimen (12). There are some risk factors that facilitate decompensation. The main two predictive factors in progression to decompensation have been reported to be advanced age (>65 years) and albumin level of $<3.6 \mathrm{~g} / \mathrm{dL}$ (13). The development of hyperbilirubinemia during the treatment has been reported to be another facilitating factor (13). Furthermore, the rate of progression to decompensation in patients with compensated cirrhosis varies widely among patient groups. Progression to decompensation was observed in $18.52 \%$ of the patients with compensated cirrhosis, who developed hyperbilirubinemia during the PrOD regimen (13). In contrast, there are studies indicating that decompensation may develop at the rate of $2 \%$ in patients with compensated cirrhosis treated with a PrODbased regimen, however, this treatment cannot be associated with mortality (12). The possibility of hepatocellular carcinoma development has been reported to be $1.4 \%$ in the follow-up period of these cases $(10,12)$.

Table 2. Descriptive statistics of surveyed variables among patient

\begin{tabular}{|c|c|c|c|c|c|c|}
\hline \multirow{3}{*}{ Variables } & \multicolumn{2}{|c|}{ Compensated cirrhosis } & \multirow{3}{*}{$\mathbf{p}$} & \multirow{2}{*}{\multicolumn{2}{|c|}{$\begin{array}{l}\text { Non cirrhosis } \\
\text { Median } \pm \text { SD }\end{array}$}} & \multirow{3}{*}{$\mathrm{p}$} \\
\hline & \multicolumn{2}{|l|}{ Median \pm SD } & & & & \\
\hline & Pre-treatment & Post-treatment & & Pre-treatment & Post-treatment & \\
\hline Total bilirubin (mg/dL) & $0.70 \pm 0.39$ & $0.66 \pm 0.37$ & 0.623 & $0.64 \pm 0.45$ & $0.49 \pm 0.35$ & 0.000 \\
\hline ALT (IU/L) & $40.59 \pm 24.55$ & $17.77 \pm 7.22$ & 0.000 & $49.07 \pm 32.88$ & $13.94 \pm 7.27$ & 0.000 \\
\hline ALP (IU/L) & $95.59 \pm 31.36$ & $92.09 \pm 34.06$ & 0.409 & $112.18 \pm 55.56$ & $98.89 \pm 39.96$ & 0.015 \\
\hline WBCs $\left(\times 10^{9} / L\right)$ & $6.73 \pm 2.51$ & $6.78 \pm 2.62$ & 0.815 & $7.03 \pm 4.16$ & $7.20 \pm 4.47$ & 0.301 \\
\hline Platelets $\left(\times 10^{9} / \mathrm{L}\right)$ & $187.80 \pm 94.59$ & $186.38 \pm 89.55$ & 0.884 & $220.95 \pm 78.83$ & $228.41 \pm 87.78$ & 0.133 \\
\hline Hemoglobin (gm/dL) & $13.21 \pm 2.23$ & $13.10 \pm 2.01$ & 0.568 & $13.29 \pm 1.93$ & $12.35 \pm 2.21$ & 0.000 \\
\hline MELD & $11.44 \pm 6.97$ & $11.04 \pm 6.85$ & 0.007 & $8.00 \pm 3.27$ & $7.53 \pm 2.91$ & 0.069 \\
\hline Child-Pugh & $5.46 \pm 0.85$ & $5.15 \pm 0.36$ & 0.043 & $5.10 \pm 0.52$ & $5.07 \pm 0.31$ & 0.484 \\
\hline
\end{tabular}

SD: Standard deviation, ALT: Alanine aminotransferase, AST: Aspartate aminotransferase, $\gamma$ GT: Gamma-glutamyl-transferase, ALP: Alkaline phosphatase, WBC: White blood cells, PT: Prothrombin time, INR: International normalization ratio, AFP: Alpha feto protein, MELD: Model for end-stage liver disease 
It has been demonstrated that there is no difference between the sofosbuvir-based regimen and the PrOD-based regimen in terms of treatment success in patients with genotype 1 in the presence of compensated liver cirrhosis (8). In the present study, no difference has been observed between the sofosbuvir-based regimen and the PrOD-based regimen in terms of SVR-12.

Advanced age is considered as a condition that may affect SVR success. In the HCV genotype 1 cases, the post-treatment SVR-12 rates have been reported to be $94 \%$ and $100 \%$ in patients aged $\geq 65$ years and $<65$ years, respectively (14). However, PrOD regimen has been reported to be effective and reliable in patients aged $\geq 65$ years. In the present study, no statistically significant difference has been observed between the patients aged $>65$ years and $<65$ years in terms of SVR- 12 .

In a study comparing PrOD \pm RBV treatment results of cases with $\mathrm{HIV} / \mathrm{HCV}$ coinfection and cases with HCV infection alone, a $2.2 \%$ difference was observed in terms of SVR-12, but no statistically lower difference was found. In cases with coinfection alone, HCV genotype 4 has been found to be associated with nonresponse to treatment (15). In another study, the results of PrOD \pm RBV treatment in genotype 1 and 4 patients with coinfection were compared and the results were seen to be similar; SVR-12 was achieved at a rate of $97.8 \%$ and $97.6 \%$, respectively (9). When the results of two patients with HIV/HCV coinfection included in the present study were evaluated, no virological response to DAA treatment was observed in a patient with simultaneous IV drug use.

In a study comparing eight-week and 12-week treatment periods in patients with genotype $1 \mathrm{~b}$, who were treated with the PrOD regimen, SVR was achieved at a rate of $95 \%$ and $99 \%$ after eight-week and 12-week treatments, respectively and no factor related to treatment non-response was found (16). The virus may be re-detected in some cases during the HCV-RNA follow-ups after SVR. The recurrence rate is reported to be about $1 \%(7,17)$. Recurrence was observed in one of our patients at the $52^{\text {th }}$ week follow-up following the achievement of SVR. No etiological reason associated with recurrence was found.

High virological response success can also be achieved in patients who have had unsuccessful treatment experience with DAA treatment (18). A 100\% SVR-12 has been achieved with the $\mathrm{PrOD} \pm \mathrm{RBV}$ regimen in compensated cirrhotic cases, about $70 \%$ of whom have treatment experience.

Mild and moderate adverse effects may occur in patients receiving PrOD \pm RBV therapy. In particular, fatigue, headache, sleeplessness, itching, diarrhea and anemia have been reported more frequently (19). No toxic changes related to DAA treatment have been observed in laboratory parameters. Furthermore, no cases where the treatment was discontinued due to adverse effects were reported (11). However, severe adverse effects that may cause discontinuation of treatment may develop (6). In the present study, the most common adverse effect was itching and there were no adverse effects causing discontinuation of the treatment or requiring additional treatment.

Treatment of chronic liver disease with DAA can affect the physical and mental scores of the patients. Positive changes can occur in social lives in particular. More cost-effective changes can be seen in the quality of life and conditions of patients after treatment (20).
Treatment success has been found to have no significant relationship with the age, gender, previous treatment, body mass index, platelet count, international normalized ratio, and MELD score (13). However, the MELD score of $<10$ and the ALT value of $20 \mathrm{U} / \mathrm{L}$ in the $8^{\text {th }}$ week of the treatment have been demonstrated to be positive markers for the virological response (21).

Some biochemical parameters that are above the reference range before treatment may return to normal limits after DAA treatment. Moreover, white blood cell count, platelet count, and hemoglobin values may change during and after treatment. These changes have been reported in both cirrhotic and non-cirrhotic cases. Significant changes can be seen in ALT, AST, GGT, ALP, platelet count, serum albumin and total bilirubin values following the DAA treatment $(8,10,21,22)$. In the literature, there are also studies reporting that there is no significant difference in the white blood cell, hemoglobin, and platelet count (22). In the present study, a significant change has been observed in albumin, ALT, AST, GGT and AFP parameters in cirrhotic patients and total bilirubin, ALT, AST, GGT, ALP, AFP and hemoglobin parameters in non-cirrhotic patients after the treatment $(p<0.05)$.

There are scoring criteria used to assess the level of liver damage and the well-being of the patient. It is thought that DAA treatment may lead to positive changes in these criteria and decrease the fibrosis score, resulting in a reduction in the burden of disease. When the initial and post-treatment first-year MELD scores and degree of fibrosis measured using FibroScan were evaluated, a significant change has been observed in both parameters $(p<0.05)$ (10). Furthermore, it has been seen that significant changes may occur in the CHILD score and physical life score of patients following the DAA treatment (10). Contrary to this, progression to decompensation is seen in very few patients with compensated cirrhosis (23). In the present study, a decrease has been observed in the post-treatment MELD and Child-pugh scores of patients with compensated cirrhosis compared to the pre-treatment scores, but there were no significant changes. However, a significant decrease has been seen in the MELD scored of patients without cirrhosis $(p=0.007)$

\section{Study Limitations}

The main limitation of our study is that it has a retrospective design. In addition, subgroup analysis was not performed based on the accompanying risk factors, HCV-RNA levels, and histological activity indices.

\section{Conclusion}

This study consists of cases with HCV genotype $1 \mathrm{~b}$ and chronic liver disease. Regardless of age, gender, viral load, and underlying diseases, a high level of SVR has been achieved in all cases included in the study. Furthermore, returning to normal limits has been observed in indirect markers used to determine the level of liver damage. The retrospective design of this study is its weakness. However, we believe that very valuable data have been presented thanks to the results it has revealed.

\section{Ethics}

Ethics Committee Approval: This study was carried out with the approval of Ethical Committee of Namık Kemal University Faculty of Medicine (approval number: 2020.86.04.10). 
Informed Consent: Since our study was retrospective, informed consent was not used.

Peer-review: Externally peer-reviewed.

\section{Authorship Contributions}

Surgical and Medical Practices: M.D., B.T., R.K., I.E., Concept: M.D., B.T., R.K., I.E., Design: M.D., B.T., R.K., I.E., Data Collection or Processing: M.D., B.T., R.K., I.E., Analysis or Interpretation: M.D., B.T., R.K., I.E., Literature Search: M.D., B.T., R.K., I.E., Writing: M.D., B.T., R.K., I.E.

Conflict of Interest: Authors declare no conflict of interest.

Financial Disclosure: There was no aid and sponsor for this study.

\section{References}

1. Tozun N, Ozdogan O, Cakaloglu Y, Idilman R, Karasu Z, Akarca U, Kaymakoglu S, Ergonul O. Seroprevalence of hepatitis B and C virus infections and risk factors in Turkey: a fieldwork TURHEP study. Clin Microbiol Infect. 2015;21:1020-1026.

2. Afdhal NH. The natural history of hepatitis C. Semin Liver Dis 2004;24 Suppl 2:3-8.

3. Zarębska-Michaluk D, Piekarska A, Jaroszewicz J, Klapaczyński J, Mazur W, Krygier R, Belica-Wdowik T, Baka-Ćwierz B, Janczewska E, Pabjan P, Dobracka B, Lorenc B, Tudrujek-Zdunek M, Tomasiewicz K, Sitko M, Garlicki A, Czauż-Andrzejuk A, Citko $J$, Dybowska D, Halota W, Pawłowska M, Laurans $Ł$, Deroń Z, Buczyńska I, Simon K, Białkowska J, Tronina O, Flisiak R. Comparative effectiveness of 8 versus 12 weeks of Ombitasvir/ Paritaprevir/ritonavir and Dasabuvir in treatment-naïve patients infected with HCV genotype 1b with non-advanced hepatic fibrosis. Adv Med Sci. 2019;65:12-17

4. Aygen B, Demirtürk N, Türker N, Asan A, Eraksoy H, Gürbüz Y, Inan D, Keten D, Koçulu S, Öncü S, Özkaya D, Saltoğlu N, Sayan M, Süer K, Şener A, Tekin S, Tuna N, Yazıcı S. Kronik Hepatit C Virusu Infeksiyonunun Yönetimi: Türk Klinik Mikrobiyoloji ve Infeksiyon Hastalıkları Derneği Viral Hepatit Çalışma Grubu Uzlaşı Raporu-2017 Güncellemesi. Klimik Dergisi. 2017;30:Özel Sayı 2-36.

5. Backus LI, Belperio PS, Shahoumian TA, Mole LA. Direct-acting antiviral sustained virologic response: Impact on mortality in patients without advanced liver disease. Hepatology. 2018;68:827838.

6. Lobato CMO, Codes L, Silva GF, Souza AFM, Coelho HSM, Pedroso MLA, Parise ER, Lima LMSTB, Borba LA, Evangelista AS, Rezende REF, Cheinquer H, Kuniyoshi ASO, Aires RS, Quintela EHD, Mendes LSC, Nascimento FCV, Medeiros Filho JEM, Ferraz MLCG, Abdala E, Bittencourt PL; Members of the Brazilian Real-Life Study about HCV treatment; Members of the Brazilian Real-Life Study about HCV treatment. Direct antiviral therapy for treatment of hepatitis C: A real-world study from Brazil. Ann Hepatol. 2019;18:849-854.

7. Wedemeyer $H$, Craxí A, Zuckerman E, Dieterich $D$, Flisiak $R$, Roberts SK, Pangerl A, Zhang Z, Martinez M, Bao Y, Calleja $\mathrm{JL}$. Real-world effectiveness of ombitasvir/paritaprevir/ritonavir \pm dasabuvir \pm ribavirin inpatients with hepatitis $C$ virus genotype 1 or 4 infection: A meta-analysis. J Viral Hepat. 2017;24:936-943.

8. Abdulla $\mathrm{M}$, Ali $\mathrm{H}$, Nass $\mathrm{H}$, Khamis J, AlQamish J. Efficacy of directacting antiviral therapy for hepatitis $\mathrm{C}$ viral infection. Real-life experience in Bahrain. Hepat Med. 2019;11:69-78.

9. Wu J, Huang $P$, Fan $H$, Tian $T$, Xia $X, F u ~ Z$, Wang $Y, Y e$ $X$, Yue $M$, Zhang $Y$. Effectiveness of ombitasvir/paritaprevir/ ritonavir, dasabuvir for HCV in HIV/HCV coinfected subjects: a comprehensive analysis. Virol J. 2019;16:11.
10. Poordad F, Castro RE, Asatryan A, Aguilar H, Cacoub P, Dieterich D, Marinho RT, Carvalho A, Siddique A, Hu YB, Charafeddine M, Bondin M, Khan N, Cohen DE, Felizarta F. Long-Term Safety and Efficacy Results in Hepatitis C Virus Genotype 1-Infected Patients Receiving Ombitasvir/Paritaprevir/Ritonavir + Dasabuvir \pm Ribavirin in the TOPAZ-I and TOPAZ-II Trials. J Viral Hepat. 2020;27:497-504.

11. Isakov V, Paduta D, Viani RM, Enejosa JV, Pasechnikov V, Znoyko O, Ogurtsov P, Bogomolov PO, Maevskaya MV, Chen X, Shulman NS. Ombitasvir/ paritaprevir/ ritonavir+dasabuvir+ribavirin for chronic hepatitis $\mathrm{C}$ virus genotype $1 \mathrm{~b}$-infected cirrhotics (TUROUOISE-IV). Eur J Gastroenterol Hepatol. 2018;30:1073-1076.

12. Chen $\mathrm{CH}$, Chen $\mathrm{CH}$, Lin $\mathrm{CL}$, Lin $\mathrm{CY}$, Hu TH, Tung SY, Hsieh SY, Lu $\mathrm{SN}$, Chien RN, Hung $\mathrm{CH}$, Sheen IS. Real-world safety and efficacy of paritaprevir/ritonavir/ombitasvir plus dasabuvir \pm ribavirin in patients with hepatitis $C$ virus genotype 1 and advanced hepatic fibrosis or compensated cirrhosis: a multicenter pooled analysis. Sci Rep. 2019;9:7086.

13. Hsieh $Y C$, Jeng WJ, Huang $C H$, Teng $W$, Chen WT, Chen $Y C$, Lin SM, Tai DI, Lin CY, Sheen IS. Hepatic decompensation during paritaprevir/ritonavir/ombitasvir/dasabuvir treatment for genotype 1b chronic hepatitis C patients with advanced fibrosis and compensated cirrhosis. PLoS One. 2018;13:e0202777.

14. Uojima H, Kobayashi S, Hidaka H, Kinbara T, Fujikawa T, Nakayama T, Yamanoue H, Kanemaru T, Hashimotoh T, Hyun Sung J, Kako M, Koizumi W. Efficacy and Tolerability of Ombitasvir/ Paritaprevir/ Ritonavir in HCV Genotype 1-infected Elderly Japanese Patients. Ann Hepatol. 2019;18:109-115.

15. Manuel Sousa J, Vergara M, Pulido F, Sánchez Antolín G, Hijona $L$, Carnicer F, Rincón D, Salmerón J, Mateos-Muñoz B, Jou A, Polo-Lorduy B, Rubín Á, Escarda A, Aguilar P, Aldámiz-Echevarría T, García-Buey L, Carrión JA, Hernández-Guerra M, ChimenoHernández S, Espinosa N, Morillas RM, Andrade RJ, Delgado M, Gallego A, Magaz M, Moreno-Planas JM, Estébanez Á, Rico M, Menéndez F, Sampedro B, Morano L, Izquierdo S, Zozaya JM, Rodríguez M, Morán-Sánchez S, Lorente S, Martín-Granizo I, VonWichmann MÁ, Delgado M, Manzanares A. Real-world evidence of the effectiveness of ombitasvir-paritaprevir/r \pm dasabuvir \pm ribavirin in patients monoinfected with chronic hepatitis $\mathrm{C}$ or coinfected with human immunodeficiency virus-1 in Spain. PLoS One. 2019;14:e0225061.

16. Zarębska-Michaluk D, Piekarska A, Jaroszewicz J, Klapaczyński J, Mazur W, Krygier R, Belica-Wdowik T, Baka-Ćwierz B, Janczewska E, Pabjan P, Dobracka B, Lorenc B, Tudrujek-Zdunek M, Tomasiewicz K, Sitko M, Garlicki A, Czauż-Andrzejuk A, Citko $J$, Dybowska D, Halota W, Pawłowska M, Laurans $Ł$, Deroń Z, Buczyńska I, Simon K, Białkowska J, Tronina O, Flisiak R. Comparative effectiveness of 8 versus 12 weeks of Ombitasvir/ Paritaprevir/ritonavir and Dasabuvir in treatment-naïve patients infected with HCV genotype 1b with non-advanced hepatic fibrosis. Adv Med Sci. 2019;65:12-17.

17. Hajarizadeh B, Cunningham EB, Valerio H, Martinello M, Law M, Janjua NZ, Midgard H, Dalgard O, Dillon J, Hickman M, Bruneau J, Dore GJ, Grebely J. Hepatitis C reinfection after successful antiviral treatment among people who inject drugs: A metaanalysis. J Hepatol. 2020;72:643-657.

18. Hunyady B, Abonyi M, Gerlei Z, Gervain J, Horváth G, Jancsik V, Lengyel G, Makkai E, Pár A, Péter Z, Pusztay $M$, Ribiczey P, Rókusz L, Sarrazin C, Schneider F, Susser S, Szalay F, Tornai I, Tusnádi A, Újhelyi E, Werling K, Makara M. Ombitasvir/ paritaprevir/ ritonavir + dasabuvir + ribavirin in HCV genotype 1 infected patients who failed previous protease inhibitor therapy. Clin Exp Hepatol. 2018;4:83-90.

19. Liu JP, Cheng YQ, Zhang JM, Jin HM, Ning HB, Li K, Ma MY, Wu YN, Peng Z, Yin H, Liu CP, Shang J. [A real-world study of paritaprevir/ritonavir-ombitasvir combined with dasabuvir in the treatment of genotype 1b chronic hepatitis C]. Zhonghua Gan Zang Bing Za Zhi. 2018;26:927-932. 
20. Shafie AA, Abu Hassan MR, Ong SC, Virabhak S, Gonzalez YS. Cost-Effectiveness Analysis of Ombitasvir/Paritaprevir/Ritonavir and Dasabuvir with or without Ribavirin Regimen for Patients Infected with Chronic Hepatitis C Virus Genotype 1 in Malaysia. Value Health Reg Issues. 2020;21:164-171.

21. De Pace V, Morelli MC, Ravaioli M, Maggi F, Galli S, Vero V, Re MC, Cescon M, Pistello M. Efficacy, Safety, and Predictors of Directacting antivirals in Hepatitis C Virus Patients with Heterogeneous Liver Diseases. New Microbiol. 2019;42:189-196.

22. Örmeci N, Sezgin O, Karaali R, Aygen B, Turan D, Yaras S, Erdem I, Yildiz O, Karakaya F, Ateş K, Asiller ÖÖ. Effectiveness of fixed-dose combination of paritaprevir, ritonavir, ombitasvir, and dasabuvir in patients with chronic hepatitis $C$ virus infection and chronic kidney diseases: real-life experiences. Eur J Gastroenterol Hepatol. 2019;31:534-539.

23. Garcia-Pajares F, Tejedor-Tejada J, Torres-Yuste R, AlmohallaAlvárez C, Sánchez-Ocaña R, Peñas-Herrero I, Cimavilla-Román M, de Benito-Sanz M, Sánchez-Martín F, Sánchez-Antolín G. Efficacy of Direct-acting Antivirals to Improve Clinical Condition, Fibrosis, and Liver Function in Liver Transplant Recipients Infected by Hepatitis C. Transplant Proc. 2019;51:74-76. 